\title{
The Exchange Rate Response of Credit-Constrained Exporters: The Role of Location
}

\section{Trond-Arne Borgersen}

Department of Economics, Social Sciences and Languages, Østfold University College, Halden, Norway

Email: trond.a.borgersen@hiof.no

How to cite this paper: Borgersen, T.-A. (2016) The Exchange Rate Response of Credit-Constrained Exporters: The Role of Location. Theoretical Economics Letters, 6, 927941.

http://dx.doi.org/10.4236/tel.2016.65096

Received: August 21, 2016

Accepted: September 17, 2016

Published: September 20, 2016

Copyright $\odot 2016$ by author and Scientific Research Publishing Inc. This work is licensed under the Creative Commons Attribution International License (CC BY 4.0).

http://creativecommons.org/licenses/by/4.0/

\begin{abstract}
This paper analyses the exchange rate response of credit-constrained exporters and highlights location-driven balance sheet effects residing both on the real side and on the financial side of the economy. A model focusing the location of production relative to both credit markets and to the first and the second hand market for capital inputs introduces a number of balance-sheet driven exchange rate effects. When it comes to location, we consider four regimes, referred to as a developed, a developing and two transition economies that differ with respect to production technology and credit market structure, respectively. The export supply response differs both across countries at different stages of development as well as between countries with different strategies to globalisation.
\end{abstract}

\section{Keywords}

Exports, Exchange Rate Response, Collateral, Balance Sheet Effects

\section{Introduction}

The response of exports to changes in the nominal exchange rate is notoriously weak [1]. The theoretical relation between exchange rates and trade was earlier argued using the elasticity approach, where the J-curve and the Marshal-Lerner condition were the building blocks ${ }^{1}$. The core assumption of the elasticity approach is, even though the short-run differs from the long-run, a positive relation between depreciations and ex-

${ }^{1}$ While the Marshal-Lerner condition is a steady-state relation based on long-run price elasticises is the J-Curve a description of the short-run trade balance response to exchange rate shocks (Meade [2]). Both theorems were initially derived in a situation where the exchange rate was pegged and capital movements played a minor role (Pitchford [3]). See also the seminal Obstfeld and Rogoff [4] paper for the relation between trade and exchange rates. 
ports.

In the aftermath of the financial crisis some episodes of large depreciations appeared to have had little impact on exports [5]. Incomplete exchange rate pass-through to (domestic) prices is a part of the explanation for the weak link between exchange rates and exports (see for instance Goldberg and Knetterer [6], Nahamura and Zermon [7], Rodriguez-Lopez [8] or Aubion and Ruta [9] for comprehensive surveys). A number of explanations have been put forward for the less than perfect pass-through, ranging from pricing to-market (see Atkeson and Burstein [10]) and local distribution costs (see Corsetti and Dedola [11]) to short-run nominal rigidities (see Gopinath, Itskhoki and Rigobon [12]).

Variations in exchange rate pass-through create variations in export supply responses. Today there seems to be variations in the export supply response across countries, sectors and time periods. Freund and Pierola [13] find that depreciations stimulate exports in developing but not in developed economies. Eichengreen and Gupta [14] indicate stronger export responsiveness to exchange rates for services than for goods, while Ahmed et al. [5] show reduced export responsiveness post 2000. Looking beyond countries, sectors and time periods the role of cross-border production has lately become the focus of attention when analysing the relation between exchange rates and trade flows. Amiti et al. [15] for instance shows lower responsiveness in Belgian firms with higher import shares while Ahmed et al. [5] finds weaker responsiveness for countries integrated in global value chains.

This paper aims to investigate the relation between exchange rates and exports highlighting the role of economic integration. However, instead of a conventional global value chain approach (see for instance Koopman et al. [16]), we consider a flow-offunds constraint taking the economy's global market integration into account. The implication of where production is located, relative to the location of the credit market and the first- and the second-hand market for capital inputs, for the transmission of exchange rates into exports is the focus of attention.

The paper allows a flow-of-funds constraint to govern the behaviour of credit-constrained exporters and compares the export supply response (to a depreciation) across four different regimes. The regimes are referred to as a developed economy, a developing economy and two transition economies with different production technology and credit market structure, respectively. A developed economy exporter faces a flow-offunds constraint but finds both credit and capital inputs at home. The export response is determined by an income effect. In a developing economy the credit-constrained exporter finds both credit and capital inputs abroad. This introduces a cost channel, a collateral channel, a wealth channel and a funding channel for how the exchange rate impacts export supply.

Turning to our two transition economies, one imports capital inputs while the other develops its capital inputs at home. This is due to that the former transition economy has a domestic production structure that mirrors the international production structure, while the production structure of the latter is developed locally. While the latter economy has both the first- and the second hand market for capital inputs at home, finds 
the former both markets abroad. International first- and second hand markets for capital inputs brings exchange rate effects into the flow-of-funds constraint through both the cost- and the collateral channel as in the case of a developing economy. We also allow transition economies to differ in terms of whether or not the credit market is domestic. If not, the flow-of-funds constraint contains, as in the case of a developing country exporter, a funding channel for the exchange rate.

To characterise our two transition economies we mix the production structure and the credit market location, in a way still not captured by neither a developed nor a developing country exporter. The two transition economies are thus either characterised by the combination of a foreign credit market and a domestic production structure or by the combination of a domestic credit market and an international production structure. This places transition economies in between the developed and the developing economy, but also allowing for different paths to global integration. The interaction between the balance-sheet effects that accompany the various combinations of the location of production relative to the location of the credit market and the first- and the second-hand market for capital inputs creates a context specific export supply response that differ both between countries at different stages of development and across transition economies with different strategies to globalisation.

The rest of the article is structured as follows. In the second part we discuss our approach in relation to relevant literature. In the third part we classify four regimes and present the model structure. The fourth part sets out the expressions for export supply and derives the export supply response to exchange rate shocks. The last part concludes.

\section{Related Literature}

Our framework is motivated by the seminal Bernanke and Gertler [17] paper highlighting the role of credit-constraints. Applying a flow-of-funds constraint Krugman [18], Aghion, Bachetta and Banerjee [19] and Cespedes, Chang and Velasco [20] amongst others, questioned the textbook effect of depreciations on exports, and argued the possibility of contractionary effects. Analysing the export supply response of a representative credit-constrained exporter assuming different national economic structures this paper allows for both expansionary and contractionary effects of a depreciation.

We position our reasoning between four regimes, referred to as a developed, a developing and two transition economies, a credit importing and a capital importing transition economy, respectively. The regimes produces an alternative framing of an economy's global integration, compared to for instance the global value chain approach. The possibility to import inter-mediaries keeps the distinction between forward- and backward linkages and upstream or downstream location still relevant (see again Koopman, Wang and Wei [16]).

The advantage of the partial flow-of-funds approach is that it allows us to explicitly distinguish between an income channel, a cost channel, a wealth channel, a funding channel and a collateral channel for the exchange rate. The flow-of-funds constraint al- 
lows us to highlight both the integration of an economy's financial- and the integration of economy's real side into the global economy. The impact of the features residing on the real side of the economy, that is the income channel and the cost channel, is well known and analysed both within intra- and industry models for trade (see for instance Smith [21] for a standard approach to trade theory). The impact on trade from the financial factors, highlighted by the funding channel and the collateral channel, is on the other hand not yet that well established, but is analysed by Amiti and Weinstein [22] Antras and Foley [23] amongst others. The flow-of-funds approach allows us to analyse the interaction between the financial and the real side. Gopintha [24] relates creditconstraints explicitly to both an exporter's marginal cost and to the exporter's mark-up, relating both the income channel and the cost channel to the credit constraint while Strasser [1] shows how credit-constrained exporters that can not afford to do Pricing-to-Market (PTM) is more inclined to pass-through exchange rates than exporter's than can, introducing a divergence in the income channel between exporters that are credit-constrained and exporters that are not.

A framework based on a representative credit-constrained exporter is partial in nature and abstracts away from, amongst other factors, the distinction between both large and small, as well as between high and low performing exporters. Amiti et al. [15] argue that the exchange rate pass-through of large exporters has decreased, while Berman et al [25] put forward the same argument for high performing firms. As both these two type of firms have gained importance in international markets, absorbing exchange rate movements in one's mark-up might have become more common, thereby also reducing the exchange rate elasticity of foreign trade over the last decades.

The representative exporter also ignores the distinction between the tradable and the non-tradable sector and the interaction between domestic and international collateral constraints as highlighted by Schneider and Tornell [26]. The distinction between the tradable and the non-tradable sector is especially important for economic growth in transition economies (see for instance Borgersen and King [27]). However, while abstracting away from the two-sector framework the distinction between a domestic and an international production structure, brings transition back into the game. Our two transition economies, where one applies a production technology developed locally while the other imports the production technology that is applied internationally, can be seen as the situation before transition begins and after the economy is fully integrated into the global economy, respectively. While stylized, the distinction draws attention to transition in general, and, more specifically, to how the role of collateral changes during the transition process. Combining the two production structures with a foreign and a domestic credit market, respectively, allows us to extract the effect of debt composition on the exchange rate channel separating between a funding channel and a collateral channel. Following the Latin American crisis of the 90s where dollarization played an important role, debt composition became the focus of attention. Bonomo et al. [28] for instance, analysed the Brazilian case while Benavente et al. [29] did the same for Chile. Basically, as surveyed by Galindo et al. [30], there is evidence if favour of the 
Cespedes, Chang and Velasco [20] argument where large levels of foreign debt (and capital market imperfections) might produce contractionary effects of a depreciation. Our credit-constraint framework draws on Bleakly and Cowen, but instead of having net-worth impacting the cost of borrowing is net-worth limiting the availability of credit, along the lines of Aghion, Bacchetta and Banerjee [19]. This brings both the credit cycle argument of Kiyotaki and Moore [31] and the underinsurance argument of Caballero and Krishnamurthy [32] to the table, where the exchange rate response in transition economies might be more uncertain than in both developed and developing economies. Basically, the interaction between the different exchange rate channels produces a context-specific relation between exports and the exchange rate. The export elasticity might change over time and vary across countries with different integration to the global economy, be it developed or developing economies or transition economies with different economic structures or different strategies to globalisation.

\section{Regime Classification and the Flow-of-Funds Constraint}

We consider a firm that produces exclusively for the international market. The exporter needs external capital to take advantage of improved international market conditions, and credit is the only type of capital available. The exporter is credit-constrained and faces a flow-of-funds constraint. To attract credit collateral is needed and capital inputs, which either are imported or produced at home, serve as collateral. In the case of imports, is the second-hand market for capital inputs abroad, as capital inputs has no alternative use at home. If, on the other hand, capital inputs are produced at home, the second-hand market is domestic. To highlight the role of location complete passthrough is assumed, making the income effect of a depreciation equal for all, irrespective of location.

Based on the location of the credit market and the first- and second hand markets for capital inputs we introduce four regimes (see Table 1):

- A developed economy. The credit market is domestic, capital inputs are produced at home and the second hand market for capital inputs is domestic.

- A technology importing transition economy. The credit market is domestic, but capital inputs are imported and the second-hand market is abroad.

- $A$ credit importing transition economy. The credit market is abroad, but the production of capital inputs and the second-hand market are domestic.

- A developing economy. The credit market, as well as the first- and the second market for capital inputs, are both located abroad.

Table 1. Regime classification.

\begin{tabular}{ccc}
\hline & A domestic credit market & A foreign credit market \\
\hline $\begin{array}{c}\text { A domestic first and second } \\
\text { hand market for capital }\end{array}$ & A developed economy & $\begin{array}{c}\text { A credit importing } \\
\text { transition economy }\end{array}$ \\
$\begin{array}{c}\text { A foreign first and second } \\
\text { hand market for capital }\end{array}$ & $\begin{array}{c}\text { A technology importing } \\
\text { transition economy }\end{array}$ & A developing economy \\
\hline
\end{tabular}


While a developed economy is completely integrated in the global economy is the situation the opposite for a developing economy, as it neither is connected to the global credit market nor applies a global production structure. The two transition economies might be seen as economies with different strategies to globalization, alternatively as transition economies at different stages of the globalization process where economies, when producing for exports, at first applies a local production structure while later in the globalization process starts adapting the international production structure.

The flow-of-funds constraint. The exporter faces a flow-of-funds constraint each period where the sum of income and borrowing constrain the amount that may be spent on wages, investments and interest payments on the prevailing debt. Debt is restricted by collateral. As some sluggishness is assumed in the default process, collateral is constrained by the present value of capital inputs.

The flow-of-funds constraint is:

Export income + debt $=$ wage costs + investment costs + interest payments

where the components are derived as follows:

Production technology. The firm exports good $X$ which is produced using labour $N$ and capital $K$ as inputs. The production function is

$$
X_{t}=K_{t}^{\alpha} N_{t}^{1-\alpha}, \alpha \in\langle 0,1\rangle
$$

which, by normalising labour $N_{t}=N=1$, allows us to express production per employee $x_{t}$ as

$$
x_{t}=k_{t}^{\alpha}
$$

Export income. The firm exports all of its production and export income (EI) equals

$$
E I_{t}=e_{t} p_{t}^{*} k_{t}^{\alpha}
$$

where $e_{t}$ is the exchange rate, defined as a higher value represents a weaker currency. The international market price of $X$ is given by $p_{t}^{*}$.

Investment cost. Investments equal the difference between the capital stock in the beginning $k_{t-1}$ and in the end $k_{t}$ of period $t$ (we abstract away from depreciations). When the first-hand market for capital inputs is domestic, and $q_{t}$ is the period t domestic market price on capital inputs, investment costs (IC) equals

$$
I C_{t}=q_{t}\left(k_{t}-k_{t-1}\right)
$$

When the first-hand market is abroad, and capital inputs are imported, investment costs equal

$$
I C_{t}^{*}=e_{t} q_{t}^{*}\left(k_{t}-k_{t-1}\right)
$$

where $q_{t}^{*}$ is the international market price on capital inputs in period $t$.

Credit-constraints and the second hand market for capital inputs. The credit market is characterised by asymmetric information and debt is restricted by its collateral value. Capital inputs can be bought at home or abroad and, as capital is assumed to be culture-specific the second hand market where collateral can be traded, is thus either domestic or foreign. 
When both the credit market and the markets for capital input are domestic, debt $b_{t}^{H}$ is constrained by the expression

$$
R b_{t}^{H} \leq k_{t} q_{t+1}
$$

where $R$ is the discount factor and $q_{t+1}$ the period $t+1$ domestic market price on capital inputs.

Equation (5) states that the discounted value of debt cannot exceed the collateral value, which equals the present value of capital inputs in the domestic market.

When, on the other hand, the exporter borrows at home but both the first- and the second hand market for capital input are foreign, debt $\hat{b}_{t}^{H}$ is constrained by the expression

$$
R \hat{b}_{t}^{H} \leq e_{t+1} q_{t+1}^{*} k_{t}
$$

where $e_{t+1}$ is the exchange rate and $q_{t+1}^{*}$ the period $t+1$ international market price on capital inputs.

When the exporter borrows abroad and both the first- and the second hand market for capital inputs are foreign, debt $\hat{b}_{t}^{F}$ is constraint by the interaction between the international market price on capital inputs in period $t+1$ and the exchange rate, where now both the current and the expected future exchange rate $e_{t+1}$ is included.

$$
e_{t} R \hat{b}_{t}^{F} \leq e_{t+1} q_{t+1}^{*} k_{t}
$$

In the fourth scenario is the credit market foreign, but both the first- and the second-hand market for capital inputs domestic. Debt $b_{t}^{F}$ is now determined by the expression

$$
e_{t} R b_{t}^{F} \leq k_{t} q_{t+1}
$$

as funding is foreign but the second hand market for capital, where collateral can be traded, is domestic. As the exporter is credit-constrained, it is by definition less patient than the market and all debt restrictions are in the following assumed to hold with equality.

\section{The Export Supply Response}

When combining the flow-of-funds constraint with the expressions for export income, investment costs and the relevant credit-constraint expression, we find both the export supply and the export supply response to a depreciation across our four regimes. At first we consider a credit-constrained exporter located in a developed economy in order to highlight the conventional income effect.

\subsection{An Exporter in a Developed Economy}

For an exporter in a developed economy both the credit market and the first- and the second hand market for capital inputs are domestic. Inserting for investment cost, and letting represent wages, the flow-of-funds constraint equals

$$
e_{t} p_{t}^{*} k_{t-1}^{\alpha}+b_{t}^{H}=w+q_{t}\left(k_{t}-k_{t-1}\right)+R b_{t-1}^{H} .
$$


When inserting for $b_{t}^{H}$ we can express exports from a developed economy exporter $k_{t}^{D C}$ as:

$$
k_{t}^{D C}=\left[\frac{1}{q_{t}-q_{t+1} / R}\right]\left\{e_{t} p_{t}^{*} k_{t-1}^{\alpha}-w+k_{t-1} q_{t}-b_{t-1}^{H}\right\} \Rightarrow k_{t}^{D C}=\frac{n w_{t}^{D C}}{u c_{t}^{D C}}
$$

Export is determined by the interaction between the user cost of capital $u c_{t}^{D C}$ and the net-worth of the exporting firm $n w_{t}^{D C}$. While the user cost equals $\left(q_{t}-q_{t+1} / R\right)$ is the net-worth given as $\left\{e_{t} p_{t}^{*} k_{t-1}^{\alpha}-w+k_{t-1} q_{t}-b_{t-1}^{H}\right\}$ and is determined by exportable income $e_{t} p_{t}^{*} k_{t-1}^{\alpha}$ plus the domestic market value of capital inputs $q_{t} k_{t-1}$ less wages and the prevailing level of debt $b_{t-1}^{H}$.

When analysing the export supply response the only exchange rate effect that comes into play is a conventional income effect. We find that a depreciation impacts positively on export supply as long as the user cost is positive $\left(u c_{t}>0\right)^{2}$.

$$
\frac{\delta k_{t}^{D C}}{\delta e_{t}}=\frac{1}{u c_{t}^{D C}} p_{t}^{*} k_{t-1}^{\alpha}>0
$$

Being contingent on the user cost, the export supply response deviates from the textbook case even for an exporter from a developed economy. As the income effect is positively related to user cost, so is the export supply response. Figure 1 pictures the positive relation between export supply and the exchange rate (assuming a positive user cost). The export response is positively influenced by both international market prices and export volumes, as indicated by the shift in the export supply curve from $S_{0}$ to $S_{1}$.

\section{Export supply}

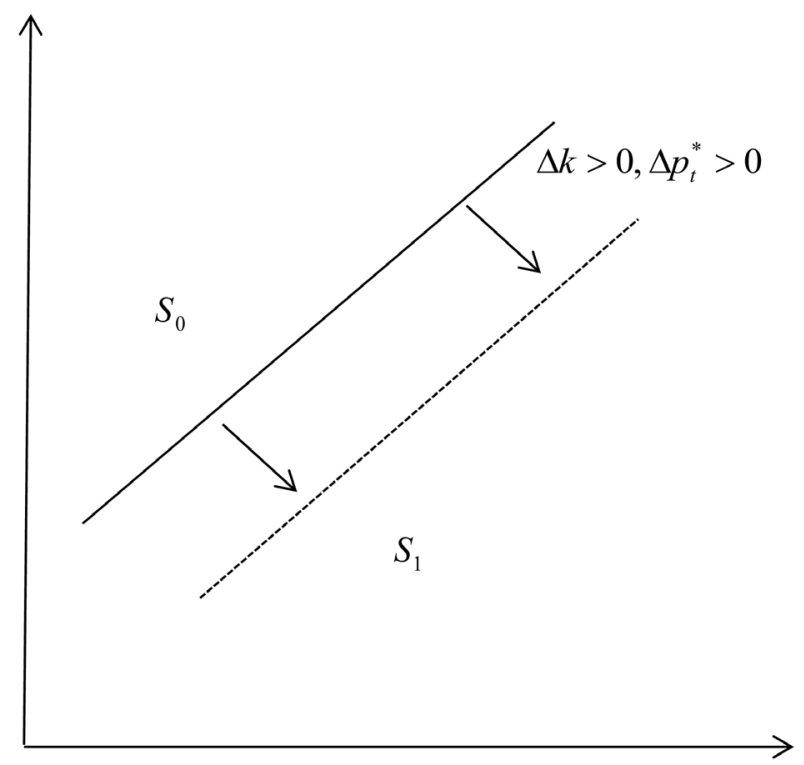

The exchange rate

Figure 1. The exchange rate response of a credit constrained exporter.

${ }^{2}$ In the following we assume the user cost to be positive. 


\subsection{An Exporter in a Developing Economy}

For an exporter in a developing economy both the credit market as well as the first- and the second hand market for capital inputs are foreign, and additional channels emerge for the exchange rate impact on exports. The flow-of-funds constraint equals

$$
e_{t} p_{t}^{*} k_{t-1}^{\alpha}+\hat{b}_{t}^{F}=w+q_{t}^{*} e_{t}\left(k_{t}-k_{t-1}\right)+R \hat{b}_{t-1}^{F} .
$$

By inserting for $\hat{b}_{t}^{F}$ export supply $k_{t}^{L D C}$ equals

$$
k_{t}^{L D C}=\left[\frac{1}{\left(e_{t} q_{t}^{*}-\frac{e_{t+1} q_{t+1}^{*}}{e_{t} R}\right)}\right]\left\{e_{t} p_{t}^{*} k_{t-1}^{\alpha}-w-R \hat{b}_{t-1}^{F}+e_{t} q_{t}^{*} k_{t-1}\right\} \Rightarrow k_{t}^{L D C}=\frac{n w_{t}^{L D C}}{u c_{t}^{L D C}}
$$

Exports is again determined by the exporter's net-worth $\left\{e_{t} p_{t}^{*} k_{t-1}^{\alpha}-w-R \hat{b}_{t-1}^{F}+e_{t} q_{t}^{*} k_{t-1}\right\}$ and the user cost of capital $\left(e_{t} q_{t}^{*}-\frac{e_{t+1} q_{t+1}^{*}}{e_{t} R}\right)$. The user cost is affected by the international market prices on capital inputs (both in the first- and in the second hand market) as well as both the current and the future exchange rate.

In addition to the income effect is the export response also characterised by a wealth effect $\left\{e_{t} q_{t}^{*} k_{t-1}\right\}$, a cost effect $\left(e_{t} q_{t}^{*}\right)$, a funding effect and a collateral effect. The latter two are related to the present value component $\left(\frac{e_{t+1} q_{t+1}^{*}}{e_{t} R}\right)$. While the denominator $\left(\frac{1}{e_{t} R}\right)$ captures the funding effect is the collateral effect given by $\left(e_{t+1} q_{t+1}^{*}\right)$.

A depreciation impacts the export supply response negatively through the cost effect and through the funding effect. As both capital inputs and credit are imported, a weaker currency raises the cost of both, thereby impacting negatively on exports. The positive income effect is supported by the wealth effect, and potentially also by the collateral effect. This is due to that a weaker currency increases the international value of exporters today (the wealth effect) and (potentially) also tomorrow (the collateral effect).

Before we derive the export supply response we need to make assumptions regarding the exchange rate process. While the wealth effect is determined by the current exchange rate, is as mentioned the collateral effect contingent on how the exchange rate is expected to evolve. Collateral might, instead of having a positive impact as indicated above, have a negative impact.

We consider three cases, starting with a simplifying assumption of static expectations. Thereafter we consider rational expectations and a stationary exchange rate and then the case with adaptive expectations.

Assuming static expectations $\Delta e_{t+1}=0$ and thereby fixing $e_{t+1}$ at its current level, we indirectly abstract away from the collateral effect. The export supply response now equals 


$$
\frac{\delta k_{t}^{L D C}}{\delta e_{t}}=\frac{1}{u c_{t}^{L D C}}\left(p_{t}^{*} k_{t-1}^{\alpha}+q_{t}^{*} k_{t-1}\right)-\frac{n w_{t}^{L D C}}{\left(u c_{t}^{L D C}\right)^{2}}\left(q_{t}^{*}+\frac{e_{t+1} q_{t+1}^{*}}{e_{t}^{2} R}\right)
$$

The response is determined by the interaction between the income effect and the wealth effect (the first two terms in expression 14) and the cost effect and the funding effect (the last two terms in expression 14), where the impact of the latter two is negative.

Inserting for $\hat{b}_{t}^{F}$ and $k_{t}^{L D C}$ we express the condition for $\frac{\delta k_{t}^{L D C}}{\delta e_{t}}>0$ in terms of a critical exchange rate

$$
e_{t}^{S}>\frac{\hat{b}_{t}^{F}}{p_{t}^{*} k_{t-1}^{\alpha}+q_{t}^{*} k_{t-1}-k_{t} q_{t}^{*}}
$$

The critical exchange rate $e_{t}^{S}$ is positively related to $\hat{b}_{t}^{F}$ (the funding effect) and $k_{t} q_{t}^{*}$ (the cost effect). The higher the import intensity and the more indebted the firm the weaker is the exchange rate necessary for a positive export response to a depreciation. On the other hand, both the income effect and the wealth effect push for a positive export response at stronger currency values.

When expectations are rational and the exchange rate is mean-reverting (operationalised by $\left.\Delta e_{t}=-\Delta e_{t+1}\right)$ the export supply response equals

$$
\frac{\delta k_{t}^{L D C}}{\delta e_{t}}=\frac{1}{u c_{t}^{L D C}}\left(p_{t}^{*} k_{t-1}^{\alpha}+q_{t}^{*} k_{t-1}\right)-\frac{n w_{t}^{L D C}}{\left(u c_{t}^{L D C}\right)^{2}}\left(q_{t}^{*}+\frac{e_{t+1} q_{t+1}^{*}}{e_{t}^{2} R}+\frac{q_{t+1}^{*}}{e_{t} R}\right)
$$

After rearranging, and (again) inserting for $\hat{b}_{t}^{F}$ and $k_{t}$, the condition for $\frac{\delta k_{t}^{L D C}}{\delta e_{t}}>0$ is expressed in terms of the critical exchange rate $e_{t}^{M R}$

$$
e_{t}^{M R}>\frac{\hat{b}_{t}^{F}+\frac{q_{t+1}^{*}}{R}}{p_{t}^{*} k_{t-1}^{\alpha}+q_{t}^{*} k_{t-1}-k_{t} q_{t}^{*}}
$$

Compared to static expectations the critical rate is higher, and a weaker currency is now necessary for a positive export supply response. This is because the collateral effect has a negative impact on export supply when the exchange rate is mean-reverting as a depreciation in period $t$ is followed by an appreciation in period $t+1$.

When expectations are adaptive (operationalised by assuming $\Delta e_{t}=\Delta e_{t+1}$ ) the export supply response is

$$
\frac{\delta k_{t}^{L D C}}{\delta e_{t}}=\frac{1}{u c_{t}^{L D C}}\left(p_{t}^{*} k_{t-1}^{\alpha}+q_{t}^{*} k_{t-1}\right)-\frac{n w_{t}^{L D C}}{\left(u c_{t}^{L D C}\right)^{2}}\left(q_{t}^{*}+\frac{e_{t+1} q_{t+1}^{*}}{e_{t}^{2} R}-\frac{q_{t+1}^{*}}{e_{t} R}\right)
$$

The condition for $\frac{\delta k_{t}^{L D C}}{\delta e_{t}}>0$ is now, except from that adaptive expectations allows the collateral effect to impact positively on the export supply response, analogue to the case with rational expectations, and the critical exchange rate $e_{t}^{E}$ equals 


$$
e_{t}^{E}>\frac{\hat{b}_{t}^{F}-\frac{q_{t+1}^{*}}{R}}{p_{t}^{*} k_{t-1}^{\alpha}+q_{t}^{*} k_{t-1}-k_{t} q_{t}^{*}}
$$

When comparing the critical exchange rates of our three cases we find $e_{t}^{M R}>e_{t}^{S}>e_{t}^{E}$ a ranking determined by how the expected exchange rate impact the collateral effect.

\subsection{An Exporter in a Credit Importing Transition Economy}

In a transition economy where the production structure is developed locally but funded abroad, the flow-of-funds constraint equals

$$
e_{t} p_{t}^{*} k_{t-1}^{\alpha}+b_{t}^{F}=w+q_{t}\left(k_{t}-k_{t-1}\right)+R b_{t-1}^{F}
$$

Inserting for $b_{t}^{F}$ and rearranging allows us to express exports from a credit importing transition economy $k_{t}^{C T}$ as

$$
k_{t}^{C T}=\left[\frac{1}{\left(q_{t}-\frac{q_{t+1}}{e_{t} R}\right)}\right]\left\{e_{t} p_{t}^{*} k_{t-1}^{\alpha}-w+q_{t} k_{t-1}-R b_{t-1}^{F}\right\} \Rightarrow k_{t}^{C T}=\frac{n w_{t}^{C T}}{u c_{t}^{C T}}
$$

Export is again determined by net-worth $\left\{e_{t} p_{t}^{*} k_{t-1}^{\alpha}-w-R b_{t-1}^{F}+q_{t} k_{t-1}\right\}$ and the user cost of capital $\left(q_{t}-\frac{q_{t+1}}{e_{t} R}\right)$. The user cost is determined by domestic market prices, but related to the exchange rate through the funding effect. The export supply response equals

$$
\frac{\delta k_{t}^{C T}}{\delta e_{t}}=\frac{1}{u c_{t}^{C T}}\left(p_{t}^{*} k_{t-1}^{\alpha}\right)-n w_{t}^{C T} \frac{q_{t+1} / R e_{t}^{2}}{\left(u c_{t}^{C T}\right)^{2}}=\frac{1}{u c_{t}^{C T}}\left[\left(p_{t} k_{t-1}^{\alpha}\right)-\frac{n w_{t}}{u c_{t}} \frac{q_{t+1}}{e_{t}^{2} R}\right]
$$

and is determined by the interaction between the (positive) income effect and the (negative) funding effect. Assuming a positive user cost, using the definition of $b_{t}^{F}$ from (8) and the expression for $k_{t}^{C T}$ given by (21), the condition for $\frac{\delta k_{t}^{C T}}{\delta e_{t}}>0$ is

$$
e_{t}^{C T}>\frac{b_{t}^{F}}{p_{t}^{*} k_{t-1}^{\alpha}}
$$

The critical exchange rate $e_{t}^{C T}$ necessary for a positive export supply response is higher the more indebted the exporter, while the level of export income allows for a positive export supply response at stronger currency values.

\subsection{An Exporter in a Technology Importing Transition Economy}

For an exporter importing capital inputs, but funding itself in domestic credit markets is the flow-of-funds constraint:

$$
e_{t} p_{t}^{*} k_{t-1}^{\alpha}+\hat{b}_{t}^{H}=w+e_{t} q_{t}^{*}\left(k_{t}-k_{t-1}\right)+R \hat{b}_{t-1}^{H}
$$

Inserting for debt-using expression (6)-allows us to express exports from a tech- 
nology importing transition economy $k_{t}^{T}$ as

$$
k_{t}^{T}=\left[\frac{1}{\left(e_{t} q_{t}^{*}-\frac{e_{t+1} q_{t+1}^{*}}{R}\right)}\right]\left\{e_{t} p_{t}^{*} k_{t-1}^{\alpha}-w-R \hat{b}_{t-1}^{H}+e_{t} q_{t}^{*} k_{t-1}\right\} \Rightarrow k_{t}^{T}=\frac{n w_{t}^{T}}{u c_{t}^{T}}
$$

For this exporter net-worth $\left\{e_{t} p_{t}^{*} k_{t-1}^{\alpha}-w-R \hat{b}_{t-1}^{H}+e_{t} q_{t}^{*} k_{t-1}\right\}$ includes both an income effect and a wealth effect while the user cost $\left(e_{t} q_{t}^{*}-\frac{e_{t+1} q_{t+1}^{*}}{R}\right)$ entails a cost effect and a collateral effect.

Applying the mean-reverting assumption from above, and inserting for $\Delta e_{t}=-\Delta e_{t+1}$, the export supply response is

$$
\frac{\delta k_{t}}{\delta e_{t}}=\frac{1}{u c_{t}^{T}}\left\{\left[p_{t}^{*} k_{t-1}^{\alpha}+q_{t}^{*} k_{t-1}\right]-\frac{n w_{t}^{T}}{u c_{t}^{T}}\left[q_{t}^{*}+\frac{q_{t+1}^{*}}{R}\right]\right\}
$$

After some rearranging and inserting for $\hat{b}_{t}^{H}$ we find the condition for $\frac{\delta k_{t}^{T}}{\delta e_{t}}>0$ as

$$
e_{t+1}>\frac{\hat{b}_{t}^{H}}{p_{t}^{*} k_{t-1}^{\alpha}+q_{t}^{*} k_{t-1}-k_{t} q_{t}^{*}}
$$

When importing capital the condition for a positive export supply response is expressed in terms of a critical future expected exchange rate, highlighting the role of collateral. As the sources of funding are located at home while the second hand market is abroad is the condition for a positive export supply influenced by the present value of collateral, which here is represented by the expected future exchange rate.

\section{Conclusions}

This paper analyses how credit-constrained exporters responds to depreciations. It presents a partial model where balance-sheet effects are influenced by location. The focus of the paper is how the location of production, relative to both credit markets and the first- and the second-hand market for capital inputs, affect the transmission of exchange rates to exports.

To give our framework some purchase we position our reasoning between four regimes referred to as a developed economy, a developing economy and two transition regimes with different adaption to both credit markets and production technology respectively.

When exporters are located in developed economy depreciations stimulate exports through a conventional income effect, as long as the user cost of capital is positive. As a positive response is contingent on the user cost, the textbook relation between the exchange rate and exports is questioned even for exporters in developed economies.

In a developing economy where exporters import both capital inputs and funding is the effect of a depreciation determined by the income effect's interaction with a wealth effect, a cost effect, a collateral effect and a funding effect. The condition for a positive 
export supply response is given in terms of a critical exchange rate. While the income effect and the wealth effect pulls the critical rate towards weaker currency levels, is the impact from the cost effect and the funding effect the opposite. There is in addition a collateral effect influenced by the (expected) future exchange rate. When the exchange rate is mean-reverting the collateral effect pushes the critical rate towards stronger currency values.

Also for transition economy exporters, where either credit or capital inputs are imported, and the export supply response therefore lacks either the cost effect or the funding effect, is the response to a depreciation in general uncertain.

In all regimes is the export supply response highly context specific and, even for a developed economy exporter, there is a potential deviation from the textbook case. The location-driven balance sheet effects show how both the existence of a domestic credit market and the location of where capital inputs are produced and may be traded matter for how exports respond to depreciations. The context specific response shows how elasticities may differ across countries, industries and time periods.

\section{Acknowledgements}

The author would like to thank an anonymous referee for helpful comments on an earlier version of the paper.

\section{References}

[1] Strasser, G. (2013) Exchange Rate Pass-Through and Credit Constraints. Journal of Monetary Economics, 60, 25-38. http://dx.doi.org/10.1016/j.jmoneco.2012.10.013

[2] Meade, E.E. (1988) Exchange Rates, Adjustment and the J-Curve. Federal Reserve Bulletin, 633-644.

[3] Pitchford, J. (1995) The Current Account and Foreign Debt. Routledge, London and New York. http://dx.doi.org/10.4324/9780203031049

[4] Obstfeld, M. and Rogoff, K. (2000) The Six Major Puzzles in International Macroeconomics: Is There a Common Cause? NBER Macroeconomics Annual.

[5] Ahmed, S., Appendino, M. and Ruta, M. (2015) Depreciations without Exports? Global Value Chains and the Exchange Rate Elasticity of Exports. The World Bank, Policy Research Working Paper 7390. http://dx.doi.org/10.1596/1813-9450-7390

[6] Goldberg, P. and Knetterer, M. (1997) Goods Prices and Exchange Rates: What Have We Learned. Journal of Economic Literature, 35, 1243-1272.

[7] Nakamura, E. and Zerom, D. (2010) Accounting for Incomplete Pass-Through. Review of Economic Studies, 77, 1192-1230. http://dx.doi.org/10.1111/j.1467-937x.2009.589.x

[8] Rodrigues-Lopez, J.A. (2011) Prices and Exchange Rates: A Theory of Disconnect. Review of Economic Studies, 78, 1135-1177. http://dx.doi.org/10.1093/restud/rdq031

[9] Aubion, M. and Ruta, M. (2013) The Relationship between Exchange Rates and International Trade: A Literature Review. World Trade Review, 12, 577-605. http://dx.doi.org/10.1017/S1474745613000025

[10] Atkeson, A. and Burstein, A. (2008) Trace Costs, Pricing-to-Market and International Relative Prices. American Economic Review, 98, 1998-2031. http://dx.doi.org/10.1257/aer.98.5.1998 
[11] Corsetti, G. and Dedola, L. (2005) Macroeconomics of International Price Discrimination. Journal of International Economics, 67, 129-165.

http://dx.doi.org/10.1016/j.jinteco.2004.09.009

[12] Gopinath, G., Itskhoki, O. and Rigobon, R. (2010) Currency Choice and Exchange Rate Pass-Through. American Economic Review, 100, 304-336.

http://dx.doi.org/10.1257/aer.100.1.304

[13] Freund, C. and Pierola, M.D. (2012) Export Surges. Journal of Development Economics, 97, 387-395. http://dx.doi.org/10.1016/j.jdeveco.2011.06.008

[14] Eichengreen, B. and Gupta, P. (2013) The Real Exchange Rate and Export Growth: Are Services Different? The World Bank, Policy Research Working Paper Series 6629.

[15] Amiti, M., Itskohi, O. and Konings, J. (2014) Importers, Exporters and the Exchange Rate Disconnect. American Economic Review, 104, 1942-1978. http://dx.doi.org/10.1257/aer.104.7.1942

[16] Koopman, R., Wang, Z. and Wei, S.J. (2014) Tracing Value-Added and Double Counting in Gross Exports. American Economic Review, 104, 459-494. http://dx.doi.org/10.1257/aer.104.2.459

[17] Bernake, B. and Gertler, M. (1989) Agency Costs, Net Worth and Business Fluctuations. American Economic Review, 79, 14-31.

[18] Krugman, P. (1999) Balance Sheets, the Transfer problem and Financial Crisis. In: Isard, P., Rasin, A. and Rose, A., Eds., International Finance and Financial Crisis, Kluwer Academic Publishers, 459-472, Berlin. http://dx.doi.org/10.1007/978-94-011-4004-1_2

[19] Aghion, P., Bacchetta, P. and Banerjee, A. (2001) Currency Crises and Monetary Policy in a Credit-Constrained Economy. European Economic Review, 45, 1121-1150. http://dx.doi.org/10.1016/S0014-2921(00)00100-8

[20] Céspedes, L.F., Chang, R. and Velasco, A. (2004) Balance Sheets and Exchange Rate Policy. The American Economic Review, 94, 1183-1193. http://dx.doi.org/10.1257/0002828042002589

[21] Smith, P.J. (2014) Global Trade Policy: Questions and Answers. Wiley Blackwell, West Sussex.

[22] Amiti, M. and Weinstein, D.E. (2011) Exports and Financial Shocks. The Quarterly Journal of Economics, 126, 1841-1877.

[23] Antràs, P. and Foley, F.C. (2011) Regional Trade Integration and Multinational Firm Strategies. In: Barro, R.J. and Lee, J.-W., Eds., Costs and Benefits of Economic Integration in Asia, Chap. 8, Oxford University Press, New York.

[24] Gopinath, G. (2013) Exchange Rate Pass-Through and Credit Constraints: Firms Price to Market as Long as They Can. Journal of Monetary Economics, 60, 39-41. http://dx.doi.org/10.1016/j.jmoneco.2012.11.004

[25] Berman, N., Martin, P. and Mayer, T. (2012) How Do Different Exporters React to Exchange Rate Changes? Theory, Empirics and Aggregate Implications. The Quarterly Journal of Economics, 127, 437-493. http://dx.doi.org/10.1093/qje/qjr057

[26] Schneider, M. and Tornell, A. (2004) Balance Sheet Effects, Bailout Guarantees and Financial Crises. Review of Economic Studies, 78, 883-913.

[27] Borgersen, T.A. and King, R. (2014) Export-Led Growth in Transition Economies: The Role of Industrial Structure, Productivity Growth Differentials, and Cross-Sectoral Subsidies. Eastern European Economics, 52, 33-54. http://dx.doi.org/10.2753/EEE0012-8775520302

[28] Bonomono, M., Martins, B. and Pinto, R. (2003) Debt Composition and Exchange Rate 
Balance Sheet Effects in Brazil: A Firm Level Analysis. Emerging Market Review, 4, 368396. http://dx.doi.org/10.1016/S1566-0141(03)00061-X

[29] Benavente, J.M., Johnson, C.A. and Morande, F.G. (2003) Debt Composition and Balance Sheet Effects of Exchange Rate Depreciations: A Firm Level Analysis for Chile. Emerging Market Review, 4, 397-416. http://dx.doi.org/10.1016/S1566-0141(03)00062-1

[30] Galindo, A., Panizza, U. and Sciantarelli, F. (2003) Debt Composition and Balance Sheet Effects of Currency Depreciation: A Summary of the Micro Evidence. Emerging Market Review, 4, 330-339. http://dx.doi.org/10.1016/S1566-0141(03)00059-1

[31] Kiyotaki, N. and Moore, J. (1997) Credit Cycles. Journal of Political Economy, 105, 211248. http://dx.doi.org/10.1086/262072

[32] Caballero, R. and Krishnamurthy, A. (2003) Excessive Dollar Debt, Financial Development and Underinsurance. Journal of Finance, 58, 867-893.

http://dx.doi.org/10.1111/1540-6261.00549

Submit or recommend next manuscript to SCIRP and we will provide best service for you:

Accepting pre-submission inquiries through Email, Facebook, LinkedIn, Twitter, etc.

A wide selection of journals (inclusive of 9 subjects, more than 200 journals)

Providing 24-hour high-quality service

User-friendly online submission system

Fair and swift peer-review system

Efficient typesetting and proofreading procedure

Display of the result of downloads and visits, as well as the number of cited articles

Maximum dissemination of your research work

Submit your manuscript at: http://papersubmission.scirp.org/

Or contact tel@scirp.org 